\title{
Association of Serum Adipokines Levels with Glycemic Control and Metabolic Dyslipidemia in Sudanese Patients with Type 2 Diabetes Mellitus
}

Halima Babiikir Eltahir ( $\sim$ halimaeltahir@hotmail.com )

Ahfad University for Women School of Medicine https://orcid.org/0000-0002-7645-4960

Elmahdi Mohamed Ali

University of Khartoum Faculty of Medicine,department of internal medicine

Abdelrahim Osman Mohamed

university of khartoum,faculty of medicine, department of biochemistry

Research article

Keywords: Type 2 diabetes mellitus, HbA1c, Adiponectin, Leptin, Sudan

Posted Date: June 30th, 2020

DOI: https://doi.org/10.21203/rs.3.rs-37122/v1

License: (c) (i) This work is licensed under a Creative Commons Attribution 4.0 International License.

Read Full License 


\section{Abstract}

Background: The pathogenesis of type 2 diabetes mellitus is due to two major abnormalities including insulin resistance and dysfunction, which lead to the inability to regulate blood glucose level. Adiponectin is a hormone secreted by the adipose tissue and it takes part in glucose metabolism with insulinsensitising properties. Low levels of adiponectin leads to reduction of fatty acid oxidation decreased glucose uptake in skeletal muscle cells and increased level of free fatty acids leading to insulin resistance. Leptin is another adipokine produced by adipose tissue involved in the control of food intake via its action on the hypothalamus, suppressing appetite and stimulating energy expenditure. Leptin plays a critical role in pathophysiology of type 2 diabetes mellitus.

The aim of the study was to investigate the association of serum adipokines levels with glycemic control and metabolic dyslipidemia in Sudanese patients with type 2 diabetes mellitus.

Methods: This was a case control study. 202 patients with type 2 diabetes and 102 non-diabetic controls participated after signing written consent. Weight $(\mathrm{kg})$ and height $(\mathrm{m})$ were measured then the body mass index $(\mathrm{kg} / \mathrm{m} 2)$ was determined. Blood samples were collected after an overnight fasting. FBG, HbA1c and lipid profiles were measured using enzymatic methods. Adiponectin and leptin were measured using sandwich ELISA.

Results: Adiponectin concentrations was significantly lower in patients with type 2 diabetes compared with the controls $(p<0.001)$ and it was inversely correlated with HbA1c (Pearson Correlation -.160 , P value $=0.005)$, total cholesterol and LDL levels $(P=0.05)$ and direct correlated HDL levels $(P=0.05)$. Leptin concentrations was significantly higher in patients with type 2 diabetes compared with the controls $(p<0.002)$ and it was positively correlated with $\mathrm{HbA} 1 \mathrm{c}$ (Pearson Correlation .155, P value $=0.02$ ), total cholesterol and LDL levels $(P=0.05)$, there were no correlation with HDL and TG levels. Patients had significantly higher fasting blood glucose, $\mathrm{HbA1c}$ levels, total cholesterol and LDL levels compared with the controls.

Conclusion: Patients with type 2 diabetes mellitus had decreased levels of serum adiponectin, high levels of serum leptin. There were significant correlations found between adiponectin and leptin levels with glycemic control and metabolic dyslipidemia .

\section{Background}

Diabetes mellitus (DM) is a chronic metabolic disorder characterized by hyperglycemia as a result of pancreatic B-cell dysfunction and insulin resistance [1].The number of adults with diabetes mellitus has been increasing annually, it is expected that more than 640 million adults will have diabetes by 2040[2]. DM occurs throughout the world but is more common (especially type 2) in more developing countries. The fastest prevalence increase is expected to occur in Asia and Africa, where most people with diabetes will probably be found by 2030 [3]. In 2011 WHO estimated that in the African region 14.7 million adults was living with diabetes mellitus, the African Region is expected to have the largest proportional increase 
of all of WHO's regions (90.5\%) in the number of adult diabetics by 2030 [4]. DM has a high risk of disabilities, decrease in quality of life due to a serious medical problem that causes many serious complications such as diabetic neuropathy, retinopathy, nephropathy and atherosclerotic vascular disease [5]. DM is a major cause of death in most countries, it accounts for 5.1 million deaths worldwide every year [6]. The diagnosis of diabetes mellitus is clinical and is based on multiple measurements of blood glucose; it is generally classified into two main types (1 and 2), with type $2 \mathrm{DM}$ accounting for more than $90-95 \%$ of the cases [7].

Type 2 diabetes mellitus constitutes up to $95 \%$ of all diabetes, with prevalence of $1.2 \%$ in developed countries, whereas in developing countries the prevalence is assumed to be fourfold higher [8,9]. Type 2 diabetes mellitus is characterized by chronic hyperglycemia resulting from defects in insulin secretion and/or insulin action and metabolic disorders of protein and lipids [10,11]. The pathogenesis of type 2 diabetes mellitus is due to two major abnormalities including insulin resistance and dysfunction of insulin production, which lead to the inability to regulate blood glucose level [12], resulting in insufficient production of adiponectin and increased production of pro-inflammatory cytokines as a result of the major contributing factors to type 2 diabetes mellitus such as obesity, dyslipidemia, hypertension and other metabolic disorders. $[13,14,15]$.

Adipose tissue, in addition to being a fat store, secretes a number of hormones and proteins collectively termed adipokines [16]. Adiponectin is a 244-amino acid collagen-like protein mainly produced in adipocytes, its production can sometimes occur or be up-regulated in other tissues such as the liver, skeletal muscle, and cardiac muscle especially in the presence of inflammation $[17,18]$. It acts as a hormone with anti-inflammatory and insulin sensitizing properties as well as its role in glucose metabolism [19,20]. Animal studies and metabolic studies in humans have shown that adiponectin improves insulin sensitivity and decreases the risk of type 2 diabetes through several mechanisms including suppression of hepatic gluconeogenesis, stimulation of fatty acid oxidation in the liver, stimulation of fatty acid oxidati on and glucose uptake in skeletal muscle, and stimulation of insulin secretion $[19,21]$.

Adiponectin is encoded by the adipose most abundant gene transcript 1 (APM1) located on chromosome $3 q 27$ [22]. This gene is abundantly expressed in adipocytes and circulates in the blood at high concentrations, which is among the highest plasma concentrations of a circulating protein.(ref) In humans, adiponectin plasma levels range from 3 to $30 \mu \mathrm{g} / \mathrm{mL}$ [23]. Plasma adiponectin levels decrease in parallel with the progression of insulin resistance, suggesting that a reduction in circulating adiponectin may be related to the development of insulin resistance [24, 25]. Serum adiponectin concentrations are reported to decrease in patients with Type 2 diabetes mellitus, obesity and coronary heart disease [26]. Adiponectin exerts its effects by binding to two receptors, AdipoR1 and AdipoR2. AdipoR1 and AdipoR2 regulate metabolic gene expression and insulin sensitivity in insulin target tissues, and are important in the pathophysiology of insulin resistance and diabetes [27, 28, 29]. Insulin resistance leads to down regulation of adiponectin receptors in muscle and liver [30]. 
Leptin is the product of the obese gene (ob), is an adipokine produced by adipose tissue involved in the control of food intake through its action on the hypothalamus[31]. Leptin action leads to suppression of appetite, regulation of body weight by inhibiting food intake and stimulating energy expenditure [31]. Leptin plays a critical role in regulation of blood glucose by having positive interaction with insulin. Leptin is linked with body fat percentage, BMI, and insulin concentration [32]. Leptin receptors are present in the hypothalamus and in tissues regulating glucose homeostasis, including skeletal muscle, liver, pancreas, and adipose tissue [33]. Leptin has been shown to stimulate glucose uptake and fatty acid oxidation in skeletal muscle, prevent lipid accumulation in non-adipose tissues such as skeletal muscle, liver, and pancreatic B cells and to inhibit insulin secretion through leptin receptors on pancreatic B-cells [34]. Leptin is involved in pathways influencing the risk of cardiovascular disease, insulin resistance and type 2 diabetes mellitus [35]. Patients with type 2 diabetes have a remarkably increased risk of cardiovascular diseases. This increased risk has been mainly attributed to hyperglycemia, dyslipidemia and inflammatory mechanisms [36]. Dyslipidemia is a broad term used to define various lipid disorders; from hyperlipidemia to hyperlipidemia, it is a major risk factor of vascular complications in patients with type 2 DM [37], dyslipidemia includes higher low-density lipoprotein cholesterol (LDL), hypertriglyceridemia (TG), low high-density lipoprotein cholesterol (HDL),and mixed lipid disorder[38]. Recently Metabolic Dyslipidemia" is commonly being used to reflect abnormal lipid pattern dominant in patients with type 2 DM [39]. Adipose tissue plays a major role in pathogenesis of dyslipidemia, several studies have demonstrated that impaired adipokines secretion causing inflammation in adipose tissue, can lead to dyslipidemia [40].

The aim of the study was to investigate the association of serum adipokines levels with glycemic control and metabolic dyslipidemia in Sudanese patients with type 2 diabetes mellitus.

\section{Materials And Methods:}

This was a case- control study conducted at Jabir Abu Eliz Diabetic center in Khartoum, Sudan. Two hundred and two patients with type 2 diabetes mellitus aged 40-59 years, diagnosed according to the criteria of the WHO FBG $\geq 126 \mathrm{mg} / \mathrm{dL}(7.0 \mathrm{mmol} / \mathrm{L})$ and who attended the diabetes clinic on Sundays and Tuesdays during the study period between February and December 2014 were included in the study after signing written consent. One hundred and two age matched healthy volunteers were included as controls. The controls had normal FBG $<110 \mathrm{mg} / \mathrm{dl}(<7.0 \mathrm{mmol} / \mathrm{l})$. This study was approved by the ethical committee of the board of medical and health sciences, University of Khartoum and the ethical committee of the state of Khartoum ministry of health.

All participants were interviewed with a questionnaire to collect data including age, sex, duration of the disease and information related to diagnosis and follow up. Clinical examination was performed.

\section{Blood sampling:}


Blood samples were collected from all subjects in the morning after 6-8 hours overnight fast using EDTA, Sodium fluoride and plain containers and were processed as follows; EDTA blood samples were used for $\mathrm{HbA} 1 \mathrm{c}$ analysis during the same day. Then plasma and serum were separated with centrifugation and were immediately stored at $-80^{\circ} \mathrm{C}$ for subsequent assay.

\section{Laboratory analyses:}

Fasting blood glucose, total cholesterol, HDL cholesterol, LDL cholesterol, triglyceride levels were measured using enzymatic colorimetric methods. Glycosylated hemoglobin \% (HbA1c \%) was measured using boronate-affinity binding enzymatic methods using Nycocard HbA1c (Axis-shieldPoC AS, Oslo, Norway) [41]. Sandwich ELISA was used for estimation of serum adiponectin and leptin levels by using commercial ELISA Kits.

\section{Statistical analysis:}

SPSS statistics (V.20.0, IBM Corp., USA, 2010) was used for analysis of data. Students t-test for independent variables was used for comparison of means. Pearson correlation and scatter plots were used to evaluate bivariate relationships between $\mathrm{HbA} 1 \mathrm{c}$, adiponectin and leptin levels in the patients $\mathrm{P}<$ 0.05 was considered significant.

\section{Results:}

The study included 202 patients with type 2 diabetes mellitus and 102 healthy controls. Anthropometric and biochemical variables of the studied subjects are presented in Tables 1 and 2. There was no significant difference between means of age (51.9 years) for patients and controls (51.02 years) P-value $>0.05$. Systolic and diastolic blood pressure were significantly higher among patients with type $2 \mathrm{DM}$ compared with controls $(P<0.001)$, the biochemical variables $(F B G, H b A 1 c, T C, L D L)$ were significantly higher among patients compared with controls $(P<0.001)$, High density lipoprotein $(H D L)$ was significantly lower in patients $(P=0.001)$. BMI and triglycerides $(T A G)$ differences between the groups were not significant. Patients had significantly lower serum adiponectin and higher leptin levels compared with the controls $(P=0.001, p=0.002$ respectively) (Table 1$)$.

There was no significant difference in means of adiponectin and leptin in regard to gender distribution ( $P$ $>0.05$ ). (Table 2).

Among the patients, adiponectin level showed significant inverse correlations with $\mathrm{HbA1c}(P=0.01)$, total cholesterol and LDL levels $(P=0.05)$. In the control subjects, adiponectin level did not show any significant correlations with all biochemical parameters. NO significant correlation was found between adiponectin and BMI in both Patients and controls (Table 3). 
Leptin had significant positive correlations with HbA1c, Total cholesterol and LDL levels $(P=0.05)$, there were no correlation with HDL and TG levels. There was no significant correlation found between leptin and BMI in both Patients and controls (Table 3 ).

Table (1) Anthropometric and biochemical variables of patients with type 2 diabetes mellitus and controls

\begin{tabular}{|llll|}
\hline Variable & Patients & Controls & \multirow{2}{*}{ P-Value } \\
\cline { 2 - 3 } & Mean \pm S.D $(\mathbf{n = 2 0 2 )}$ & Mean \pm S.D $(\mathbf{n = 1 0 2})$ & \\
\hline Age (years) & $51.91 \pm 4.19$ & $51.02 \pm 4.31$ & 0.084 \\
\hline SBP $(\mathrm{mmHg})$ & $130.6 \pm 8.79$ & $120.5 \pm 5.98$ & 0.000 \\
\hline DBP $(\mathrm{mmHg})$ & $87.0 \pm 6.68$ & $80.3 \pm 3.36$ & 0.000 \\
\hline BMl $(\mathrm{kg} / \mathrm{m} 2)$ & $25.80 \pm 3.65$ & $24.60 \pm 4.81$ & 0.01 \\
\hline FBG $(\mathrm{mg} / \mathrm{dl})$ & $180.81 \pm 47.15$ & $100.06 \pm 13.18$ & 0.000 \\
\hline HbA1c $(\%)$ & $8.77 \pm 2.36$ & $5.09 \pm .696$ & 0.000 \\
\hline Adiponectin & $16.98 \pm 10.41$ & $21.95 \pm 13.85$ & 0.001 \\
\hline Leptin & $17.78 \pm 4.61$ & $15.96 \pm 4.93$ & 0.002 \\
\hline T C $(\mathrm{mg} / \mathrm{dl})$ & $178.67 \pm 33.54$ & $142.11 \pm 31.05$ & 0.000 \\
\hline LDL $(\mathrm{mg} / \mathrm{dl})$ & $86.28 \pm 24.030$ & $62.77 \pm 17.36$ & 0.000 \\
\hline HDL $(\mathrm{mg} / \mathrm{dl})$ & $48.52 \pm 14.29$ & $54.27 \pm 14.81$ & 0.001 \\
\hline TG $(\mathrm{mg} / \mathrm{dl})$ & $120.89 \pm 29.97$ & $119.62 \pm 32.20$ & 0.733 \\
\hline
\end{tabular}

SBP (mmHg) systolic blood pressure; DBP( $\mathrm{mmHg}$ ) diastolic blood pressure; BMI (Body Mass Index); FBS (Fasting Blood Sugar); HbA1c (Haemoglobin A1c); TC (Total cholesterol); TG (Triglycerides); HDL (High Density Lipoproteins); LDL (Low Density Lipoproteins)

Table (2) Adiponectin and leptin levels among male and female patients with type 2 diabetes mellitus

\begin{tabular}{|llll|}
\hline Variable & male Patients No 95 & Female patients No 107 & \multirow{2}{*}{ P-Value } \\
\cline { 2 - 4 } & Mean \pm S.D $(\mathbf{n}=\mathbf{2 0 2})$ & Mean \pm S.D $(\mathbf{n = 1 0 2 )}$ & \\
\hline Adiponectin & $17.8682 \pm 10.66485$ & $16.1922 \pm 10.16784$ & .255 \\
\hline Leptin & $18.0177 \pm 4.13943$ & $17.5667 \pm 5.00749$ & .489 \\
\hline
\end{tabular}

Table (3): Correlations of adiponectin with BMI, $\mathrm{HbA} 1 \mathrm{c}$ and lipid profiles in patients and control 


\begin{tabular}{|c|c|c|c|c|}
\hline \multicolumn{5}{|c|}{ Adiponectin level } \\
\hline \multicolumn{3}{|c|}{ Patients ( $n=202$ ) } & \multicolumn{2}{|l|}{ Controls $(n=102)$} \\
\hline & Pearson Correlation & P-value & Pearson Correlation & P-value \\
\hline BMI (kg/m2) & .080 & .260 & .99 & .330 \\
\hline HbA1c ( \%) & $-.197 \star \star$ & .005 & .056 & .577 \\
\hline $\mathrm{T} \mathrm{C}(\mathrm{mg} / \mathrm{dl})$ & $.139 *$ & .049 & -.110 & .275 \\
\hline LDL (mg/dl) & $.161^{*}$ & .022 & .034 & .736 \\
\hline $\mathrm{HDL}(\mathrm{mg} / \mathrm{dl})$ & $.157 *$ & .025 & .088 & .386 \\
\hline $\mathrm{TG}(\mathrm{mg} / \mathrm{dl})$ & .004 & .950 & -.130 & .199 \\
\hline \multicolumn{5}{|c|}{$\star \star P$ value $<0.01$ (2-tailed) } \\
\hline \multicolumn{5}{|c|}{${ }^{*} \mathrm{P}$ value $<0.05$ (2-tailed). } \\
\hline
\end{tabular}

Table (4): Correlations of Leptin levels with BMI, HbA1c and lipid profile in patients and control group

\begin{tabular}{|c|c|c|c|c|}
\hline \multicolumn{5}{|l|}{ Leptin level } \\
\hline \multicolumn{3}{|c|}{ Patients $(n=202)$} & \multicolumn{2}{|l|}{ Controls $(n=102)$} \\
\hline & Pearson Correlation & P-value & Pearson Correlation & P-value \\
\hline BMI (kg/m2) & .035 & .618 & .068 & .501 \\
\hline HbA1c (\%) & $.139 *$ & .048 & -.099 & .329 \\
\hline $\mathrm{T} \mathrm{C}(\mathrm{mg} / \mathrm{dl})$ & $.138 *$ & .050 & .102 & .312 \\
\hline LDL (mg/dl) & $.157^{*}$ & .026 & -.146 & .148 \\
\hline $\mathrm{HDL}(\mathrm{mg} / \mathrm{dl})$ & .020 & .782 & .137 & .174 \\
\hline $\mathrm{TG}(\mathrm{mg} / \mathrm{dl})$ & -.124 & .080 & .056 & .577 \\
\hline
\end{tabular}

\section{Discussion}

This study assessed the association of serum adipokine and leptin levels with glycemic control and dyslipidemia in Sudanese patients with type 2 diabetes mellitus.

In this study, adiponectin levels were significantly lower among patients when compared with control group. The findings of the study agreed with previous studies suggesting that adiponectin may play a role in glucose metabolism and low adiponectin levels are frequently reported in type 2 diabetes in 
different ethnic groups $[42,43]$. Higher serum adiponectin levels were reported to be associated with lower risk of diabetes among Japanese, Mexicans, Asian Indians Kashmiri and other populations [44, 45, 46]. The low levels of adiponectin seen in diabetic patients are believed to be associated with the disorder of glucose and lipid metabolism [47,48], and this explains the presence of insulin resistance in type 2 DM patients. The explanation of the association between diabetes and adiponectin could be related to the anti-diabetic effects of adiponectin. Adiponectin has been reported to promote pancreatic beta-cell function, increase insulin sensitivity by stimulating hepatic insulin signaling by enhancing Insulin receptor substrate 2 expression [49]. Adiponectin also increases glucose uptake by stimulating the translocation of the glucose transporter 4 (GLUT4) to the cell surface [50]. Adiponectin has also been reported to modulates the interaction between hepatic and skeletal muscle insulin receptors by activation of 5 adenosine monophosphate-activated protein kinase (AMPK) pathway [51]. Other potential mechanisms of the glucose lowering effect of adiponectin include; suppression of hepatic gluconeogenesis, stimulation of fatty acid oxidation in the liver, stimulation of glucose uptake and fatty acid oxidation in skeletal muscle [52]. This result demonstrates a clear significant relationship between plasma adiponectin concentration and Type 2DM. Thus, adiponectin has increasingly been considered a potential biomarker for type 2DM.

In this study, adiponectin was inversely correlated with HbA1c levels similar to previous studies [53,54], indicating that adiponectin could be used as a marker for evaluation of glycemic control and disturbance of glucose metabolism in diabetic patients. The reduction of serum adiponectin in patients was independent of their body mass indices. In contrast with the previous studies that have shown adiponectin levels negatively correlated with $\mathrm{BMI}$ and insulin resistance in diabetic patients $[55,56,57]$. However, other previous reports agreed with this study that there was no correlation between adiponectin and $\mathrm{BMI}$ in diabetic patients $[58,59]$. It could be explained by the fact that adiponectin concentrations were mostly linked with insulin sensitivity rather than insulin resistance in type 2 diabetic patients.

Leptin levels were high in the patients with type 2 diabetes compared with controls, and positively correlated with HbA1c levels in the patients. This could explain the role of leptin in glucose homeostasis. The insulin sensitizing effects of leptin have been related to increased fatty acid oxidation and decreased triglyceride storage in muscle $[60,61]$. It has been identified as an important regulator of pancretic $b$-cell mass and inhibition of insulin gene expression [62], mediation of direct inhibitory effects of leptin on insulin secretion may be disrupted under conditions of increased leptin levels such as type 2DM and obesity $[62,63]$.

The study results showed no significant difference in BMI between diabetic patients and healthy controls, in agreement with previous reports [64], serum leptin levels were not correlated with BMI in diabetic patients. In relation to this aspect, a previous study found an association between diabetes and leptin levels when BMI was adjusted in the regression model [65]. It is probable that factors other than increased body fat content also contribute to the elevated leptin levels in diabetic patients. There were some studies that have shown positive correlation between leptin and BMI in patients with type 2DM [66, 
67]. In agreement with a previous study [68], serum adiponectin and leptin levels did not vary significantly between genders although significant differences were observed in patients and controls.

Adiponectin was found to be correlated with various parameters of lipids profile, it is especially associated with HDL and TG. Adiponectin induces an increase in serum HDL and, in addition, it lowers serum TG through the enhanced catabolism of TG-rich lipoproteins [69].The findings of the current study showed that, serum lipid profile of type 2 diabetic patients was abnormal compared with those of the controls whose lipid profiles were mostly within normal values. This confirmed the well-known association of dyslipidemia with type 2 diabetes [70]. In this study the positive correlation between serum adiponectin and HDL levels in the patients, is in agreement with previous studies that reported positive correlation between HDL and adiponectin that was independent of BMI and insulin resistance in type 2 diabetic patients $[7172,73,74]$.t could be explained by the fact that decreased adiponectin levels have been related to increased hormone sensitive lipase activity, which may be responsible for the decreased levels of HDL cholesterol [75,76]. Several studies have investigated the relationship between adiponectin, LDL and TC levels, but the results were controversial, previous studies showed that the level of adiponectin has an inverse relationship with $\operatorname{LDL}$ and TG $[72,73,74]$, another study showed no significant correlation between serum adiponectin level, LDL cholesterol and total cholesterol in type 2 diabetic patients [77]. In the current study there were inverse correlations between serum adiponectin with LDL and TC in the patients, a similar study conducted in Japan showed a negative correlation between serum adiponectin levels and LDL, TC, levels in type 2 diabetics [78]. The negative correlation was explained to be due to low levels of adiponectin which is associated with reduced activation of peroxisome proliferator activator receptor-alpha (PPAR-a) receptors in the liver and decreased expression of LDL receptors in body tissues [78]. A Previous study reported inverse correlation between serum adiponectin and TG level in the type 2 diabetic patients [79].

It has been explained by the hypothesis that adiponectin may increase the production and activation of lipoprotein lipase and the expression of VLDL receptors by activation of PPAR ain liver which will reduce the storage of triglycerides in adipose tissue and their uptake by the hepatocytes and increase concentration of triglyceride in the blood (hypertriglyceridemia) [80]. In contrast, this study showed there was no correlation between serum adiponectin and TG level in the type 2 diabetic patients.

The association between leptin and lipid metabolism has been reported in animal studies, leptin deficiency has been observed to be associated with hyperglycemia, hyperlipidemia, and insulin resistance [81]. There are contradictions between the relations of serum leptin levels and lipids profile. Some studies reported that there was no relationship between leptin and the parameters of a lipid profile [82,83]. Other study showed a significant positive correlation between leptin and lipid profile (HDL, TG) [84].

In current study leptin levels seem to correlate only with selected lipid profile parameters (TC and LDL), in agreement with previous study the results showed positive correlation between leptin level and total cholesterol [85]. A study on Japanese showed that there was a significant relationship between serum leptin level and LDL in diabetic patients [86], these results are consistent with this study and another 
study conducted showed a positive correlation between serum leptin level and LDL in white subjects [87]. Despite the link between serum leptin levels and lipid metabolism and the indication that high leptin levels are biomarkers of obesity [88], this study did not demonstrate a correlation between leptin level, TG and $\mathrm{HDL}$, in agreement with a previous study [89].

\section{Conclusion}

Sudanese diabetic patients had decreased level of serum adiponectin and elevated levels of serum leptin. Serum adiponectin level is negatively associated with $\mathrm{HbA} 1 \mathrm{c}$ and serum leptin level is positively associated with $\mathrm{HbA} 1 \mathrm{c}$, the present study supports that adipokines levels associated with glycemic control and incidence of dyslipidemia in type 2 diabetes.

\section{Abbreviations}

DM: diabetes mellitus; EDTA: Ethylene diamine tetra acetic acid; HbA1c: glycated Hemoglobin; BMI: body mass index; LDL: Iow density lipoprotein; HDL: high density lipoprotein; TAG: triacylglycerol; ELISA: enzyme linked immunosorbent assay.

\section{Declarations}

\section{Availability of data and materials}

The datasets analyzed during the current study are available from the corresponding author on reasonable request.

\section{Acknowledgments}

We would like to thank Prof. Gasim Badri, President of Ahfad University for Women for his financial support and help in obtaining the study reagents and materials, We would like to thank the staff of Jabir Abu Eliz Diabetic center in Khartoum, Sudan

\section{Funding}

This research received funding from Ahfad University for Women and partial funding from Ministry of Higher Education.

\section{Authors' contributions}

Halima Babikir Eltahir (HBE) research design, patient recruitment and data collection, laboratory analysis, data analysis, manuscript drafting.. Elmahdi Mohamed Ali(EMA) research design, critical reading. 
Abdelrahim Osman Mohamed (AOM) research design, result interpretation, manuscript drafting and critical reading. All authors read and approved the final manuscript for submission and publication.

\section{Ethics declarations}

\section{Ethics approval and consent to participate}

Patients enrolled after a written consent was obtained which was approved by the ethical committee of the board of medical and health sciences, University of Khartoum and the ethical committee of the state of Khartoum ministry of health.

\section{Consent for publication}

Not applicable.

\section{Competing interests}

We have no competing interests.

\section{References}

1. Zheng Y, Ley SH, Hu FB. Global aetiology and epidemiology of type 2 diabetes mellitus and its complications. Nat Rev Endocrinol. 2018 Feb;14(2):88-98.

2. Wild S, Roglic G, Green A, Sicree R, King H. Global prevalence of diabetes: estimates for the year 2000 and projections for 2030. Diabetes Care. 2004; 27:1047-53.

3. Whiting DR, Guariguata L, Weil C, Shaw J. IDF diabetes atlas: global estimates of the prevalence of diabetes for 2011 and 2030. Diabetes Res Clin Pract. 2011; 94:311-21. doi: 10.1016/j.diabres. 2011.10.029.

4. Ahmed AM. Diabetes mellitus in Sudan: size of the problem and possibilities of efficient care. Pract Diabetes Int. 2001; 18: 324-327.

5. Bos M, Agyemang C. Prevalence and complications of diabetes mellitus in Northern Africa, a systematic review. BMC Public Health. 2013;13:387. doi:10.1186/1471-2458-13-387.

6. Guariguata L, Whiting DR, Hambleton I, et al. Global estimates of diabetes prevalence for 2013 and projections for 2035. Diabetes Res Clin Pract. 2014; 103: 137-149.

7. American Diabetes Association. Diagnosis and Classification of Diabetes Mellitus. Diabetes Care. 2014 Jan; 37(Supplement 1): S81-S90.

8. Guariguata L, Whiting DR, Hambleton I, et al. Global estimates of diabetes prevalence for 2013 and projections for 2035. Diabetes Res Clin Pract. 2014; 103: 137-149. 
9. Garber AJ, Handelsman Y, Einhorn D, et al. Diagnosis and management of prediabetes in the continuum of hyperglycemia: when do the risks of diabetes begin? A consensus statement from The American College of Endocrinology and the American Association of Clinical Endocr Pract. 2008; 14: $933-946$.

10. Yanling W, Yanping D, Yoshimasa, Wen Z. Risk Factors Contributing to Type 2 Diabetes and Recent Advances in the Treatment and Prevention. Int J Med Sci. 2014; 11(11): 1185-1200.

11. Kahn SE. Clinical review 135: the importance of beta-cell failure in the development and progression of type 2 diabetes. J Clin Endocrinol Metab. 2001; 86: 4047-4058

12. .Donath MY, Shoelson SE. Type 2 diabetes as an inflammatory disease. Nat Rev Immunol. 2011; 11: 98-107.

13. Kahn SE, Hull RL, Utzschneider KM. Mechanisms linking obesity to insulin resistance type 2 diabetes. Nature 2006; 444: 840-846.

14. Roberts CK, Hevener AL, Barnard RJ. Metabolic syndrome and insulin resistance: Underlying causes and modification by exercise training. Compr Physiol. 2013; 3: 1-58.

15. Guerre-Millo M: Adipose tissue and adipokines: for better or worse. Diabetes Metab. 2004; 30:13- 19.

16. Coelho, M., Oliveira, T. \& Fernandes, R. Biochemistry of adipose tissue: an endocrine organ. Arch Med Sci. 2013; 9:191-200.

17. Tilg $\mathrm{H}$, Moschen AR. Adipocytokines: mediators linking adipose tissue, inflammation and immunity. Nat Rev Immunol. 2006; 6(10):772£83. https://doi.org/10.1038/nri1937 PMID: 16998510.

18. Kadowaki T, Yamauchi T, Kubota N, et al. Adiponectin and adiponectin receptors in insulin resistance, diabetes, and the metabolic syndrome. J Clin Invest. 2006; 116(7):1784-1792.

19. K Ohashi, N Ouchi, Y Matsuzawa. Anti-inflammatory and anti-atherogenic properties of adiponectin. Biochimie. 2012; 94, no. 10:2137-2142.

20. Rabe K, Lehrke M, Parhofer KG, et al. Adipokines and insulin resistance. Mol Med. 2008; 14(1112):741-751.

21. Vionnet,Hani EH, Dupont S, Gallina S, Francke S, et al. Genomewide search for type 2 diabetessusceptibility genes in French whites: evidence for a novel susceptibility locus for early-onset diabetes on chromosome 3q27-qter and independent replication of a type 2 diabetes locus on chromosome 1q21 - Am J Hum Genet. 2000; 67: 1470-1480.

22. Pajvani UB, Du X, Combs TP, Berg AH, Rajala MW, Schulthess T, et al. Structure-function studies of the adipocyte-secreted hormone Acrp30/adiponectin. Implications fpr metabolic regulation and bioactivity. J Biol Chem. 2003;278(11):9073-85.

23. Hotta K, Funahashi T, Bodkin NL, Ortmeyer HK, Arita Y, et al. Circulating concentrations of the adipocyte protein adiponectin are decreased in parallel with reduced insulin sensitivity during the progression to type 2 diabetes in rhesus monkeys. Diabetes. 2001; 50:1126-1133.

24. De Rosa A, Ludovica Monaco M, Capasso M, et al. Adiponectin oligomers as potential indicators of adipose tissue improvement in obese subjects. European Journal of Endocrinology.2013; 169, no. 1: 
37-43.

25. Deepa V R, Pradeepa R. Association of low adiponectin levels with the metabolic syndrome-the Chennai Urban Rural Epidemiology Study (CURES-4) Metabolism. 2005; 54(4):476-481.

26. Yamauchi T, Kamon J, Ito Y, Tsuchida A, Yokomizo T, et al. Cloning of adiponectin receptors that mediate antidiabetic metabolic effects. Nature. 2003; 423:762-769.

27. Yamauchi T, Nio Y, Maki T, et al. Targeted disruption of AdipoR1 and AdipoR2 causes abrogation of adiponectin binding and metabolic actions. Nat. Med.2007; 13: 332-339.

28. Yamauchi T, Iwabu M, Okada-Iwabu, M, et al. Adiponectin receptors: a review of their structure, function and how they work. Best Pract. Res. Clin. Endocrinol. Metab.2014; 28: 15-23.

29. Tsuchida A, Yamauchi T, Ito Y, Hada Y, Maki T, Takekawa S, et al. Insulin/Foxo1 pathway regulates expression levels of adiponectin receptors and adiponectin sensitivity. J Biol Chem. 2004; 279(29):30817-22.

30. Mohiti and J. Doudi. Relation between leptin and insulin in patients with type 2 diabetes mellitus. Turkish Journal of Endocrinology and Metabolism. 2003; vol. 9, no. 2: 55-58.

31. Scarpace M, Matheny, Y. Zhang. Wheel running eliminates high-fat preference and enhances leptin signaling in the ventral tegmental area. Physiology \& Behavior.2010; vol. 100, no. 2:173-179.

32. Wauters M, Considine RV, Van Gaal L. Human leptin: from an adipocyte hormone to an endocrine mediator. Eur J Endocrinol 2000; 143:293-311.

33. Minokoshi Y, Kim YB, Peroni OD, Fryer LG, et al. Leptin stimulates fatty-acid oxidation by activating AMP-activated protein kinase. Nature 2002; 415:339-

34. Wannamethee SG, Tchernova J, Whincup P, Lowe GDO, et al. Plasma leptin: Associations with metabolic, inflammatory and haemostatic risk factors for cardiovascular disease. Atherosclerosis 2007; 191:418-426.

35. Ulijaszek SJ. Obesity: preventing and managing the global epidemic. J Biosoc Sci. 2003; 35:624-5.

36. Dandona P, Aljada A, Chaudhuri A, Bandyopadhyay A. The potential influence of inflammation and insulin resistance on the pathogenesis and treatment of atherosclerosis- related complications in type 2 diabetes. J Clin Endocrinol Metab; 2003 88:2422-2429

37. Keaney Jr JF, Curfman GD, Jarcho JA. A Pragmatic View of the New Cholesterol Treatment Guidelines. New Engl J Med. 2014; 370(3): 275 - 278.

38. Smith DG. Epidemiology of dyslipidemia and economic burden on the healthcare system. Am J Manag Care. 2007; 13: 68-71.

39. Rana JS, Visser ME, Arsenault BJ, Després JP, Stroes ES, et al. Metabolic dyslipidemia and risk of future coronary heart disease in apparently healthy men and women: The EPIC-Norfolk prospective population study. International journal of cardiology. 2010; 143: 399-404.

40. Jung UJ, MS Choi. Obesity and its metabolic complications: the role of adipokines and the relationship between obesity, inflammation, insulin resistance, dyslipidemia and nonalcoholic fatty liver disease. International journal of molecular sciences. 2014; 15: 6184-6223. 
41. Karami A, Baradaran A. Comparative evaluation of three different methods for $\mathrm{HbA}(1 \mathrm{c})$ measurement with High-performance liquid chromatography in diabetic patients. Adv Biomed Res. 2014; 3: 94. doi: 4103/2277-9175.129364.

42. Deepa M, Farooq S, Deepa R. Prevalence and significance of generalized and central body obesity in an urban Asian Indian population in Chennai. India (CURES: 47) Eur J Clin Nutr. 2009;63(2):259-267.

43. Shaibi GQ, Cruz ML, Weigensberg MJ, Toledo-Corral CM, Lane CJ, Kelly LA, Davis JN, Koebnick C, Ventura EE, Roberts CK, Goran MI. Adiponectin independently predicts metabolic syndrome in overweight Latino youth. J Clin Endocrinol Metab. 2007;92(5):1809-1813.

44. Miguel C, Rebeca GM, Yolanda GV, et al. Low adiponectin levels predict type 2 diabetes in mexican children. Diabetes Care. 2004;27(6):1451e1453.

45. Yamamoto S, Matsushita Y, Nakagawa T, et al. Circulating adiponectin levels and risk of type 2 diabetes in the Japanese. Nutr Diabetes. 2014;4(8):e130.

46. Wannamethee SG, Lowe GD, Rumley A, Cherry L, et al. Adipokines and risk of type 2 diabetes in older men. Diabetes Care 2007; 30:1200-1205.

47. Lu HL, Wang HW, Wen Y, Zhang MX, et al. Roles of adipocyte derived hormone adiponectin and resistin in insulin resistance of type 2 diabetes. World J Gastroenterol 2006; 12: 1747-51.

48. Karbowska J, Kochan Z. Role of adiponectin in the regulation of carbohydrate and lipid metabolism. J Physiol Pharmacol . 2006 ;57 Suppl 6: 103-13.

49. Awazawa M. , Ueki K, Inabe K, Yamauchi T, et al. Adiponectin enhances insulin sensitivity by increasing hepatic IRS-2 expression via a macrophage-derived IL-6- dependent pathway. Cell Metabolism 2011; 13(4):401- 12.

50. Ceddia R.B , Somwar R., Maida A, Fang X., et al. Globular adiponectin increases GLUT4 translocation and glucose uptake but reduces glycogen synthesis in rat skeletal muscle cells. Diabetologia. 2005; 48(1):132-9.

51. Yamauchi T, Kamon J, Minokoshi Y, Ito Y, Waki H, Uchida S, et al. Adiponectin stimulates glucose utilization and fatty-acid oxidation by activating AMP-activated protein kinase. Nat Med 2002; 8:1288-1295.

52. Berg AH, Combs TP, Scherer PE. ACRP30/adiponectin: An adipokine regulating glucose and lipid metabolism. Trend Endocrinol Metab 2002; 13:84-89.

53. Goodarzi MT, Babaahmadi-Rezaei H, Kadkhodaei-Eliaderani M, et al. Relationship of serum adiponectin with blood lipids, $\mathrm{HbA}(1) \mathrm{c}$, and hs-CRP in type II diabetic postmenopausal women. J Clin Lab Anal. 2007; 21(3):197-200.

54. Schulze MB1, Rimm EB, Shai I, et al. Relationship between adiponectin and glycemic control, blood lipids, and inflammatory markers in men with type 2 diabetes. Diabetes Care. 2004 Jul; 27(7):1680-7.

55. Cnop M, Havel PJ, Utzschneider KM, Carr DB, et al. Relationship of adiponectin to body fat distribution, insulin sensitivity and plasma lipoproteins: evidence for independent roles of age and sex. Diabetologia. 2003; 46(4):459-69. 
56. Weyer C, Funahashi T, Tanaka S, Hotta K, et al. Hypoadiponectinemia in obesity and type 2 diabetes: close association with insulin resistance and hyperinsulinemia. J Clin Endocrinol Metab. 2001; 86(5):1930-5.

57. Ayina et al.Association of serum leptin and adiponectin with anthropomorphic indices of obesity, blood lipids and insulin resistance in a Sub-Saharan African population. Lipids in Health and Disease. 2016; 15:96-5.

58. Abdelgadir et al. Low serum adiponectin concentrations are associated with insulin sensitivity independent of obesity in Sudanese subjects with type 2 diabetes mellitus. Diabetology \& Metabolic Syndrome. 2013; 5:15 Page 3 of 5.

59. Awede et al. Adiponectin, in contrast to leptin, is not associated with body mass index, waist circumference and HOMA-IR in subjects of a west-African population. Physiol Rep. 2018; 6 (11): e13718, page 5 .

60. Leshan RL, Björnholm M, Münzberg H, Myers MG Jr. Leptin receptor signaling and action in the central nervous system. Obesity (Silver Spring). 2006;14 Suppl 5:208S-12S.

61. Tudurí E, Marroquí L, Soriano $S$, Ropero AB, et al. Inhibitory effects of leptin on pancreatic alpha-cell function. Diabetes. 2009; 58:1616-24.

62. Lee YH, Magkos F, Mantzoros CS et al. Effects of leptin and adiponectin on pancreatic $\beta$-cell function. Metabolism. 2011; 60: 1664-1672.

63. Marroquí L, Gonzalez A, Neco P et al. Role of leptin in the pancreatic b-cell: effects and signaling pathways. J. Mol. Endocrinol.2012; 49: R9-R17

64. Mona Hmoud Al Sheikh. The Determinants of Leptin Levels in Diabetic and Nondiabetic Saudi Males. Int J Endocrinol. 2017; 2017: 3506871. 7 pages

65. Bandaru P, Shankar A. Association between plasma leptin levels and diabetes mellitus. Metab Synd and Rela Disordrs. 2011; 9(1):19 - 23.

66. Thiyagarajan M, Sunil K, Muthukrishnan Sh, et al.Evaluation of Leptin as a Marker of Insulin Resistance in Type 2 Diabetes Mellitus. Int J Appl Basic Med Res. 2017 Jul-Sep; 7(3): 176-180.

67. Anil K, Sunny Ch, Ashok K. Serum Leptin and Body Mass Index in Type 2 Diabetes Mellitus Patients of Dehradun, Uttarakhand, India. Int.J.Curr.Microbiol.App.Sci. 2015; 4(12): 434-440.

68. Tamer H. Shebla, Noor El Deen A. Azeemb, Relationship between serum leptin concentration and insulin resistance syndrome in patients with type 2 diabetes mellitus. J Curr Med Res Pract. MayAugust 2017; 2: 125-132.

69. Christou GA, Kiortsis DN. Adiponectin and lipoprotein metabolism. Obes. Rev. 2013; 14: 939-949.

70. Okafor $\mathrm{Cl}$, Fasanmade OA, Oke DA. Pattern of dyslipidaemia among Nigerians with type 2 diabetes mellitus Niger J Clin Pract. 2008; 11:25-31.

71. Mojiminiyi OA, Abdella NA, Al Arouj M, Ben Nakhi A. Adiponectin, insulin resistance and clinical expression of the metabolic syndrome in patients with type 2 diabetes. Int J Obes (Lond). 2007; 31:213-220. 
72. Durrani S, Shah J, Khan MA, Jan MR. Relationship of adiponectin level with lipid profile in type-2 diabetic men with coronary heart disease. J Ayub Med Coll Abbottabad. 2015 Jan-Mar; 27(1):325.27(1):32-35.

73. Kimm H, Lee SW, Lee HS, Shim KW, et al. Associations between lipid measures and metabolic syndrome, insulin resistance and adiponectin. - Usefulness of lipid ratios in Korean men and women. Circ J. 2010; 74(5):931-7.

74. Matsubara M, S Maruoka, S Katayose. Decreased plasma adiponectin concentrations in women with dyslipidemia. J Clin Endocrinol Metab. 2002; 87(6):2764-9.

75. Vergès B. Pathophysiology of diabetic dyslipidaemia: where are we? Diabetologia. 2015; 58:886899.

76. Schneider JG, von Eynatten M, Schiekofer S, Nawroth PP, Dugi KA. Low plasma adiponectin levels are associated with increased hepatic lipase activity in vivo. Diabetes Care. 2005; 28: 2181-2186.

77. Mantzoros CS, Li T, Manson JE, Meigs JB, Hu FB. Circulating adiponectin levels are associated with better glycemic control, more favorable lipid profile, and reduced inflammation in women with type 2 diabetes. J Clin Endocrinol 2005 Aug;90(8):4542-8.

78. Yoon MJ, Lee GY, Chung JJ, Ahn YH, Hong SH, Kim JB. Adiponectin increases fatty acid oxidation in skeletal muscle cells by sequential activation of AMP-activated protein kinase, p38mitogen-activated protein kinase, and peroxisome proliferatoractivated receptor alpha. Diabetes. 2006; 55:2562-2570.

79. Goodarzi MT, Babaahmadi RH, Kadkhonei EM, Haddadinezhad S. Relationship of serum adiponectin with blood lipids, HbA1C, and hsCRP in type II diabetic post-menopausal women. J Clin Lab Anal. 2007; 21:197-200.

80. von Eynatten M, Schneider JG, Humpert PM, Rudofsky G, et al. Decreased plasma lipoprotein lipase in hypoadiponectinemia: an association independent of systemic inflammation and insulin resistance. Diabetes Care. 2004; 27:2925- 2929.

81. Gavrilova O, Marcus-Samuels B, Graham D, Kim JK, et al. Surgical implantation of adipose tissue reverses diabetes in lipoatrophic mice. J Clin Invest. 2000; 105: 271-278.

82. Haluzik M, Fiedler J, Nedvidkova J, Ceska R: Serum leptin levels in patients with hyperlipidemias. Nutrition. 2000; 16:429-433.

83. Al-Shoumer KA, Anyaoku V, Richmond W, Johnston DG. Elevated leptin concentrations in growth hormone-deficient hypopituitary adults. Clin Endocrinol. 2000; 47:153-159.

84. Yadav A, Jyoti P, Jain SK, Bhattacharjee J. Correlation of adiponectin and leptin with insulin resistance: a pilot study in healthy North Indian population. Indian J Clin Biochem 2011; 26:193196.

85. Mirrakhimov EM, Kerimkulova A, Lunegova O, Mirrakhimov A, et al.The association of leptin with dyslipidemia, arterial hypertension and obesity in Kyrgyz(Central Asian nation) population. BMC Research notes.2014; 7: 411:415.

86. Hiroso H., Saito I., Kawabe H., Saruta T. Insulin resistance and hypertension: seven-year follow-up study in middle-aged Japanese men (the KEIO Study). Hypertension Research. 2003 Oct; 26(10):795- 
800.

87. Njajou $\mathrm{O}$, Kanaya A, Holvoet P, et al. Association between oxidized LDL, obesity and type 2 diabetes in a population-based cohort, the Health Aging and Body Composition study. Diabetes Metab Res Rev. 2009; 25(8):733-739. doi: 10.1002/dmrr.1011.

88. Vega GL, Grundy SM. Metabolic risk susceptibility in men is partially related to adiponectin/leptin ratio. J Obes. 2013; 2013:409679. doi: 10.1155/2013/409679.

89. Lubkowska A1, Radecka A1, Bryczkowska 11, Rotter I2. Serum Adiponectin and Leptin Concentrations in Relation to Body Fat Distribution, Hematological Indices and Lipid Profile in Humans Int. J. Environ. Res. Public Health. 2015; 12, 11528-11548. 